\title{
The effectiveness of selected housing subsidies in the Czech Republic
}

\author{
Martin Lux $\cdot$ Petr Sunega $\cdot$ Peter Boelhouwer
}

Received: 31 January 2008/Accepted: 15 April 2009

(C) Springer Science+Business Media B.V. 2009

\begin{abstract}
The goal of this article is to evaluate the effectiveness of the new housing policy in the Czech Republic as an example of a transitional society after the collapse of communism. The first part provides a brief history of the housing policy dating back to 1918. The second part presents the results of empirical tests of effectiveness (or equity) of selected housing subsidies applied during the transition. As in other transitional countries, the considerable decrease in the financial affordability of housing after 1989 demanded an active housing policy. Housing subsidies, whether direct or implicit, were, however, often not well targeted. The economic subsidy from rent regulation, tax relief and housing allowances are especially assessed here.
\end{abstract}

Keywords Housing policy · Welfare economics - Subsidy effectiveness · Transition economies

\section{Introduction}

After the collapse of the socialist regime, housing reform in the Czech Republic was, like in many other countries, a consequence of wider economic liberalization and political changes. The reform led to the liberalization of housing construction material prices, privatization of construction firms and the rapid introduction of a legislative framework to support the establishment of new private construction companies where salaries were

M. Lux · P. Sunega

Institute of Sociology, Academy of Sciences, Jilská 1, 11000 Prague 1, Czech Republic

M. Lux

e-mail: martin.lux@soc.cas.cz

P. Sunega

e-mail: petr.sunega@soc.cas.cz

P. Boelhouwer $(\bowtie)$

OTB Research Institute for Housing, Urban and Mobility Studies, Delft University of Technology, Jaffalaan 9, 2628 BX Delft, The Netherlands

e-mail: p.j.boelhouwer@tudelft.nl 
liberalized. Energy prices were also liberalized, although some weaker form of price regulation was established under anti-monopoly legislation. The wider political change led to the restitution of apartment buildings expropriated by the former regime to the previous owners or their descendants (part of a wider restitution process). It also led to the decentralization of power over housing policy from the center to the local level (part of a wider decentralization process). The decentralization of the housing policy in the Czech Republic has been, like in many other transitional countries, accompanied by the transfer of public rental housing from state to municipal ownership (Lowe and Tsenkova 2003; Donner 2006; Lux 2003a, b).

Though these changes were relatively common among all transitional countries, they were the logical consequences of applying wider reform packages rather than the intended goals of new housing policies in those countries. However, when particular new housing policy strategies are compared, the differences among new EU member states were much more obvious than the similarities (Lux 2006; Lowe and Tsenkova 2003; Pichler-Milanovich 2001; Struyk 1996; Clapham et al. 1996). The countries differed not only in the fact, whether there was any real housing policy applied or not, but also in the forms, targeting and goals of subsidies (Lux 2001, 2003a, b; Diamond 2005; Mandic 2000; Tosics and Hegedüs 1998). The Czech Republic belongs, together with countries like Poland and Slovenia, to the group of countries that applied a pro-active housing policy and thus several subsidies were either kept from the previous regime or introduced there (Lux 2003a, b; Dübel 2000). Against this background, the effectiveness (synonymous to equity here) ${ }^{1}$ of this specific pro-active housing policy in the Czech Republic is evaluated in this paper. More in particular we focus on the direct and fiscal housing subsidies in the Czech Republic_-namely rent regulation, housing allowance, selected supply side subsidies, state premium to housing savings schemes and tax relief. The effectiveness is understood as a degree to which the state interventions helped to redistribute housing consumption in favor of the "worse-off". The selection of subsidies for the purpose of evaluation was considerably limited due to the lack of necessary information. For most of the assessment we used the data file from the Family Budget Survey 2002. ${ }^{2}$ All the above-mentioned subsidies could be considered as a kind of income redistribution; therefore we addressed the question of whether they contribute to mitigating of income inequalities.

The article is divided into six sections. After this introduction, the second section contains an overview of the Czech housing policy, including a more detailed description of basic milestones in the Czech housing policy after the end of communism, i.e., after 1989. The third section describes the theoretical framework for measuring the effectiveness of housing policy instruments. The next section specifies the particular methodology and data sources that were employed for evaluation in the case of the Czech Republic. The results of empirical analysis are presented in the fifth section, and the article finishes with a presentation of the main conclusions.

\footnotetext{
1 Though some studies use the term "effectiveness" and some others the term "equity", both terms are, to our knowledge, mostly understood in the same way. This can be demonstrated by the well-known monograph The Economics of the Welfare State by Barr-in the 1993 edition he uses the word "effectiveness" while in the 1998 edition he prefers using the word "equity".

2 The Family Budget Survey is an annual survey of the Czech Statistical Office that is intended to record the flow of income and expenditure in household budgets using a sample of Czech households selected on a quota basis, i.e., the sample is representative of the Czech population only in terms of some of their characteristics. This shortcoming is eliminated using weights recommended by the Czech Statistical Office.
} 


\section{Housing policy in the Czech Republic from a historical perspective}

Regulatory state interventions in the area of housing have quite a long tradition in the Czech Republic. As early as the period of the First Czechoslovak Republic (1918-1939), state support of new housing construction was accompanied with measures aimed at tenant protection and housing market regulation. However, the goal of the government was to return to a free private market once the post-war housing shortage had been overcome (Mildschuh et al. 1931); WWII substantially changed such plans and rents were frozen once again. After 1948 (communist putsch) housing policy was shaped by the state. Most private apartment buildings were expropriated by the state, pre-war housing cooperatives were "nationalized" by merging their property into new large housing cooperatives. Mass production of state rental flats, since the 1960s using prefabricated technology, predominated. The state housing policy in this period was based on the principle that a flat is such an important good in the life of a person that the increase in housing costs should not be reflected in household expenditures (Poláková et al. 2006). This necessarily resulted in continually growing volumes of state subsidies for housing construction as well as for the operation, management and maintenance of the existing state housing (Lux et al. 2002; Sýkora 2003). This policy has been increasingly confronted with limited resources. Other types of housing construction (corporate, cooperative and individual) were later allowed. Individual housing construction included primarily the construction of family houses.

State dwellings were allocated on a local level. The rent was fixed at the level of 1964 prices through a legal regulation till 1990, and thus no funds were created even for the most elementary maintenance activities (Sýkora and Šimoníčková 1994). Huge subsidies to cover the costs of utilities resulted in wastage both on the production and consumption side. On the other hand, the budgets of housing cooperatives had to be in principle balanced; people living in cooperative flats thus spent more on housing than those living in state housing (Lérová 1983). Paradoxically, the cheaper state flats were allocated mostly to the communist nomenclature, leading employees of the state, members of the armed and other forces - the very same people whose incomes were higher due to the functions they held (Poláková et al. 2006). The system that tried to make housing a pure public good and one of the basic human rights lacked after several decades of operation the financial resources to fulfill its goals and was characterized by unskilled management, bureaucracy, free-riding, low-quality construction, under-maintenance, huge inefficiencies, ${ }^{3}$ and encouraged the existence of illegal practices, clientelism and corruption (Lux et al. 2004).

As in other sectors of the economy, after 1989 the housing sector began to undergo a transformation from a centrally planned and an administrative flat allocation system to a system based on market principles. Key events in housing policy during the transformation period were the restitution of part of the housing stock, the free-of-charge transfer of the un-restituted portion of the former state housing to municipal ownership, the privatization of the municipal rental housing stock, the introduction of new housing policy instruments, in particular the housing allowance, and the introduction of a housing savings scheme and mortgage loans. Another important step was the initiation of a gradual rent deregulation, which began in 1992 .

Restitution began in April 1991 and applied to the portion of the housing stock that had been confiscated by the state or became the property of the state between 1948 and 1990 under circumstances that were disadvantageous to the original owner. If the legal terms for

\footnotetext{
3 The hidden debt on housing maintenance caused by under-maintenance during the previous regime has been estimated as being 13.1-18.0 bill. EUR (Lux et al. 2004; ÚRS 2005).
} 
Table 1 Tenure structure change between 1991 and 2001

\begin{tabular}{|c|c|c|c|c|}
\hline & \multicolumn{2}{|l|}{1991} & \multicolumn{2}{|l|}{2001} \\
\hline & Abs. & In $(\%)$ & Abs. & In $(\%)$ \\
\hline Privately owned house & $1,367,027$ & 36.9 & $1,371,684$ & 35.8 \\
\hline Privately owned flat & 31,164 & 0.8 & 421,654 & 11.0 \\
\hline Municipal rental & $1,242,664$ & 33.5 & 649,656 & 17.0 \\
\hline Private rental $^{\mathrm{a}}$ & 222,567 & 6.0 & 443,294 & 11.6 \\
\hline Member of a housing co-operative & 697,829 & 18.8 & 548,812 & 14.3 \\
\hline Member of a tenant co-operative ${ }^{b}$ & - & - & 103,216 & 2.7 \\
\hline $\begin{array}{l}\text { Other (gratuitous use, caretaker and staff, } \\
\text { other and undetermined) }\end{array}$ & 144,430 & 3.9 & 289,362 & 7.6 \\
\hline Permanent-residence housing units & $3,705,681$ & 100.0 & $3,827,678$ & 100.0 \\
\hline
\end{tabular}

Source: Census 1991, 2001-Czech Statistical Office

a Estimates

b Member of a legal entity founded by tenants for the purpose of the privatization of their tenement building

the restitution of property were satisfied, the property was returned to the original owners, or to their heirs or immediate relatives. The process of decentralization of power included the transfer of the remaining public housing stock from state to municipal ownership. The municipalities were cast in the role of administrators of the housing stock, responsible for creating local housing policy. However, the transfer of the housing stock was not accompanied by any increased financial contributions to the municipal budgets.

It was assumed that the municipalities would privatize some of the newly acquired housing stock. However, there were no nationally applicable recommendations to the municipalities as to what part of the housing stock they should privatize, no recommendations relating to the prices the housing stock should be sold at. All these matters were left to the discretion of the municipalities, which inevitably meant that the conditions under which privatization proceeded varied considerably (Sýkora 2003; Lux 2004). The start of the privatization process dates back to 1991, but despite the absence of exact statistical data it can be said that the volume of privatization reached its peak in the second half of the 1990s. ${ }^{4}$ Unlike other transition countries (Lux 2003a, b), in the Czech Republic tenants did not acquire the right-to-buy that would have enabled them to request privatization of their rental flat and which the municipality would have had to comply with. As a result, the municipal rental housing sector is still relatively large.

Privatization also had an effect on the cooperative housing sector. Through a law enacted in 1994 members of a housing co-operative acquired the right to sell their flats (or more precisely, to transfer their co-operative shares) at a market price and the right to the free-of-charge transfer of a co-operative flat to their full ownership. The co-operative housing became, in fact, part of the owner-occupied housing sector. All the aforementioned processes (restitution, transfer of the housing stock from state to municipal ownership, and privatization) were reflected in a significant change in the tenure structure (Table 1). A marked increase in the percentage of privately owned flats (by more than $10 \%$ points) and conversely a reduction in the share of rental dwellings (by almost $11 \%$ points) are clear.

In spite of the restitution of properties or transfer of rental housing to municipal ownership, the state decided to uphold the main principles of the "old" rent control and

\footnotetext{
${ }^{4}$ In particular based on data from a survey conducted by the Institute for Regional Development (ÚÚR).
} 
tenant protection from the previous regime. The state kept the monopoly to direct the process of rent deregulation in the whole country. Rent deregulation started at the beginning of the 1990s. The maximum monthly regulated rent has gradually increased in relation to the quality of a flat, the size of the municipality and the inflation coefficient. In addition, market rents were allowed for new tenancies. The regulated rents remained however, still far below their market levels and were not high enough to allow the necessary housing stock modernization and refurbishment (STÚ-E 2007). The prices of utilities were liberalized far more resolutely, which resulted in a situation where the rent made up only one-third of the total housing expenditures of an average tenant household, while the remaining two-thirds of housing expenditures covered the utility payments. The deregulation process almost stopped in 1999 when the social democratic government decided to increase regulated rents only by the rate of inflation. The judicial actions of both private and municipal landlords against the State led to the formal abolishment of rent regulation by the Constitutional Court in 2000. Until 2006 there has been, however, no new Act defining further rent deregulation. Because rents could not have been increased unilaterally, regulated rents were frozen at 2002 levels during 2002-2006, this time not only in real but also in nominal values. This created grounds for heightened tensions between landlords and tenants, and the landlords started to bring charges against the Czech Republic before the Court for Human Rights in Strasbourg.

In January 1996 the Act on State Social Support, which defined the new form of the housing allowance scheme, came into effect. The housing allowance was intended for households with an income that is less than 1.6 times the subsistence minimum (to 1998 only 1.4 times the subsistence minimum). The allowance (HA) was calculated using the following equation:

$$
\mathrm{HA}=\mathrm{TC}-\frac{\mathrm{TC} \times Y}{\mathrm{SM} \times 1.60},
$$

where TC is tariff household costs, $Y$ is real household income, and SM is subsistence minimum.

The housing allowance did not take into account real but only normatively fixed (tariff) housing costs. Such tariffs were computed from the level of rents in rent-controlled housing. It was tenure neutral - it was paid to both tenants and homeowners. In 2004 about $6 \%$ of all (census) households were recipients of the housing allowance scheme. The level of allowance did not reflect existing regional differences in housing costs and/or the difference in housing costs between households living in the rent-controlled housing and households paying market rents.

Neither social housing nor not-for-profit housing associations were legally defined in the Czech Republic. The government however, started to support new municipal rental housing construction since 1995 through grants covering, a bit later on, about one-third to one-quarter of the average dwelling construction costs. Due to the fact that there were no binding cost or income ceilings (targeting) for dwelling allocation and mainly the fact that the program has been transformed in a way that allowed speculation and abuse, it was criticized and, finally, largely amended in 2003 (Lux et al. 2002, 2003). The original program allowed for the creation of housing cooperatives between municipality and participants (future "tenants"): a municipality, with the help of a commercial developer, often only secured the state subsidies. The remaining costs were covered from down-payments of future "tenants" and commercial mortgage loans. The share in the housing cooperative could be liquidated under valid legislation immediately. Many flats constructed under this program were therefore soon sold or rented out by participants profiting from state 
subsidies; moreover, some flats were constructed only as secondary homes and some as luxurious dwellings (National Control Office 2004, 2006). Since 2003 the cooperation form has been forbidden and cost and income ceilings have been introduced; on the other hand, the subsidy has been increased.

Another program in the field of supply side subsidies (since 2003) has been aimed at supporting the construction of so-called supported municipal rental flats for people who have a disadvantage in access to housing, particularly for reasons of health (people with disabilities) or age (the elderly). Supported flats also include flats in halfway houses and "start-up" flats. The subsidy (grant) recipient is a municipality or group of municipalities. The municipality must retain a majority share and is not allowed to ask for any financial contribution from future tenants. The privatization of flats into the tenants' ownership, the subleasing of flats, the sale of flats to a third party, or the mortgaging of flats for credit (with the exception of credit to acquire flats) are banned in the program.

Owing to the abrupt withdrawal of the state from financial co-involvement in housing construction, it became necessary to establish conditions conducive to the introduction of standard financial market instruments that would enable households to obtain the necessary financial resources to build or buy a flat or home. The first of such instruments was the housing savings scheme, introduced in 1993, which represents a combined savings and credit product. The state supports the saving part of the scheme by a state premium-its amount decreased in 2004 when the system was partially reformed. The value of the state premium amounts to $15 \%$ of the annual deposit up to the limit of CZK 3,000 (25\% of the sum of the annual deposit up to CZK 4,500 before 2004). Clients are entitled to be granted a "regular" housing savings loan at least after 2 years of the saving period.

Mortgage credit is clearly the most common means to finance the construction or purchase of a flat or house in developed countries. In the Czech Republic the necessary legislation for the extension of mortgage loans was passed in 1995. Mortgage financing did not spread as quickly as expected. This was mainly due to the macroeconomic situation, particularly inflation and high nominal interest rates on mortgage loans (in 1995 the nominal interest rates were around $11 \%$, and in 2000 they were still around 8.2-8.6\%). But there were also psychological reasons: people were afraid of taking on a large debt for a long term, the future course of interest rates was uncertain, and there was still a feeling that living in debt is somehow immoral (Lux et al. 2005). The state contributed to the spread of mortgage lending by interest subsidies for mortgage loans on new housing. In 1995 tax relief on interest on housing savings loans and mortgage loans was also introduced.

\section{Theoretical framework}

There might be a whole scale of possible evaluative tools to assess policies, but one of them, welfare economics, is gradually becoming a standard approach in policy studies. Housing is not a simple category that can be viewed from a single perspective. On the one hand, housing constitutes private property, traded on the market. Housing economics, however, observes the following essential differences between housing and standard market commodities (Maclennan 1982; Fallis 1985; Bull 1998; Barker 2003; Quigley 1997; Muth and Goodman 1989; Malpezzi and Green 2003; and others): it is a heterogeneous, multidimensional good; it becomes subject to both consumption and investment; it is relatively illiquid; it is spatially fixed; acquiring is connected with high transaction costs and the equilibrium on housing markets is often hard to achieve (due to low price elasticity of both demand and supply and some other inefficiencies). The high level of 
speculation (short-term investments) can increase market distortions and volatility of house prices, and contribute to undesirable price bubbles on the housing market (Abraham and Hendershott 1996; Muellbauer and Murphy 1997; and others). Finally, due to the spatial fixity of housing, many externalities (both positive and negative) appear on the housing market.

One the other hand, housing is also perceived as a basic social need of human beings. It is often called a "merit good" (Barr 1993). A merit good is a good about whose consumption there is a collective consensus of the entire society. In other words, society collectively believes that its consumption is inherently desirable and therefore, unlike the consumption of other goods, should be publicly supported. State housing policies thus challenge both the economic and social perspectives of housing; they are led both by the effort to eliminate market failures (following from defining housing as an economic good) and by the effort to redistribute housing consumption (following from the social perspective of housing). The double role of the "ideal" state may be characterized as rational economists and understanding paternalists (Lux 2003a, b). The question however, remains why the state simply does not ignore the social aspects of housing. Why does it also behave as an understanding paternalist who redistributes housing consumption?

In addition to the wide range of sociological system theories explaining the role of state interventions in the field of housing, ${ }^{5}$ there are several social justice theories based on abstract assumptions of classic rationalism that are more relevant for our purposes, such as the assumption of rational behavior. One of them is the theory of coerced redistribution. According to Downs (1957, in Barr 1998), politicians behave selfishly and with the expectation of expanding their power, status, or income, they strive to maximize the number of potential electoral votes for themselves in the next elections. And because the income distribution is unequal in most countries, politicians maximize the number of electoral votes by supporting redistribution from the wealthy to the poor. Another, voluntary redistribution theory, proposed by Hochman and Rodgers (1969, in Barr 1998) documents that it is in the rational interest of every "wealthy" person to redistribute their wealth in the direction of "poorer" fellow citizens and therefore the "wealthy" do so-not under pressure from the state, but voluntarily. The theory is based on the assumption that there are always several externalities on the market and therefore the consumption utility of each individual is significantly influenced by the consumption of others. Thus, the consumption utility of the "wealthy" is influenced by the degree or form of consumption of the "poor".

Rawls' theory of justice (Rawls 1971) became especially influential in this field. The actors in his theory follow their rational selfish interest but they are supposed to be behind a veil of ignorance, which means that they know nothing about themselves, about their histories, social status, income, expected life career. The negotiators follow their own interests but are unable to separate themselves from others. When considering the principle of justice the only rational consensus reached by negotiators would be to maximize the welfare of the least well-off individual (as nobody knows who it is and there is always some probability that each of them might be he). Such a conclusion leads to the imperative to redistribute the wealth till the point is reached when complete equality is established. The above-mentioned influential theories stressed the importance of rationality in social

\footnotetext{
5 The examples of such theories are historic determinism (Marxism), agency and corporativism (Schmidt 1989; Clapham et al. 1990; Lundqvist 1988; Boddy 1989), path dependence (Kleinman 1996), political structuralism (Lundqvist 1992), social constructivism or theories of prevailing ideology (Kemeny 1992, 1995; Boelhouwer and van der Heijden 1992).
} 
justice and set forth not practical guidelines but the "rational imperative" to redistribute housing consumption from those who are better off to those who are worse off.

The double "ideal" role of state as understanding paternalist and rational economist is reflected in policies directed towards the (economic) efficiency of market functioning and policies towards (social) effectiveness (equity) in housing consumption. ${ }^{6}$ This perfectly relates to the more general approach of welfare economics, which uses microeconomic techniques to simultaneously determine allocative efficiency within an economy and the income distribution associated with it. The concept of efficiency originated in neoclassical economics. In the field of welfare economics it was first applied to social welfare functions simply by summing comparable individual utility functions (the works of F. Y. Edgeworth, H. Sidwick, A. Marshall, as well described in Ng 1983; Just et al. 2004). However, this approach would produce rather different conclusions on "efficient" social welfare by including such "efficient" distributions that would be connected with deep income and wealth inequalities in a society. The New Welfare Economics (the works of W. Pareto, J. Hicks and others) thus distinguished the efficiency and effectiveness (equity) parts- the former is analyzed using the criteria of Pareto allocation efficiency ${ }^{7}$ while the latter can be analyzed only in close connection with particular social norms and values, welfare state regime and/or social justice theory. In this way the concept of (market) efficiency was "freed" from the influence of varied normative statements. On the other hand, the concept of effectiveness (equity) became fragmented into different theories of social justice and particular welfare state regimes.

Effectiveness relates to the "fair" distribution part of welfare economics. The redistribution of wealth (realized generally by states) forms a crucial part of the whole concept as this is the only possibility to finally reach a "fair" or "desirable" wealth distribution. The effectiveness might be understood as the degree to which the redistributive goals of state interventions (following particular social norms and welfare state regimes) are met, i.e., whether the public funds were actually spent where they were allocated and whether those to whom they were intended were actually helped. The concept of effectiveness has not, however, been left to such "definition infinity"; in such a case it would be hardly measurable and comparable. The welfare economists did not want to leave the concept of effectiveness solely to the will of the governments, who often do not define the intention of their intervention. The concept was thus based on the "rational imperative" and social justice theories described above, generalized into the assumption that whatever state redistribution of wealth is finally applied, it should decrease social inequality in society, i.e., the redistribution policies should help those worse off at the expense of those better off. The scale of such wealth redistribution may be small (residual welfare state regime) or high (social-democratic welfare state regime) but all the modern concepts of social justice share the above-stated assumption on the direction of wealth redistribution from highincome to low-income members of society. The concept of equity, equality and effectiveness are all derivates of modern liberalism and political democracy, clear and live relics of social revolutions and liberal thoughts.

\footnotetext{
${ }^{6}$ It is common for a 'trade-off' situation to arise between efficiency and equity (Barr 1998, p. 11).

7 If there is any alternative allocation of goods that would increase the utility from consumption for at least one actor on the market while it would not decrease the utility from consumption among other actors in the same time then we say that such allocation is inefficient and there is space for market performance improvement, called Pareto optimization or Pareto improvement. Such improvement may be often assured only by the state interventions.
} 
Moreover, a distinction is made between vertical and horizontal effectiveness. The former relates to "the degree of redistribution of income, consumption and wealth from the rich to the poor" (Barr 1993, p. 444). In the example of a particular housing subsidy, it measures the extent to which such a subsidy is actually allocated to those who really need help, i.e., mainly to low-income households. It also measures whether it finally decreases the income inequality in society. Horizontal effectiveness refers to the kind of distribution (of income, consumption, or wealth) that corresponds to the principle of "distribution in accordance with equal treatment of equals" (Barr 1993, p. 440). Horizontal effectiveness is therefore linked in practice with objectives such as ensuring a minimum standard of consumption of certain goods and services or equal opportunities for and equal access to these goods and services. In the example of this particular housing subsidy it measures whether there is any needy (poor) household which is not eligible to apply for the subsidy. The fact that some needy households are excluded from subsidies may be caused, for example, by the fact that the program has been set up badly or the potential claimants are badly informed (or may be afraid of potential social stigmatization).

\section{Methodology and data sources}

The lack of available statistics about the recipients of different housing subsidies means that an analysis can only be made for selected policy tools. The evaluation refers to the form of those instruments, especially in 2002. The main data source used in the analysis of the effectiveness of rent regulation and the housing allowance was the Family Budget Survey conducted by the Czech Statistical Office in 2002 (further FBS 2002). The evaluation of the effectiveness of tax relief is based on data provided by the Ministry of Finance and collected from taxpayers who submitted an income tax declaration in 2002. ${ }^{8}$ The evaluation of state premiums to housing savings as well as of supply side subsidies will be only sketched here as it cannot be based on any fully applicable data source.

Because FBS 2002 did not distinguish different social transfers, it was not clear whether a household receives housing allowances or not. Although the real take-up of housing allowance was estimated from the results of sociological surveys to be only $40 \%$ in 1996 and 60\% in 1999 (Mareš 2001), the evaluation of its effectiveness was based on the assumption of a $100 \%$ take-up. In other words, an allowance amount was imputed, on the basis of declared income, household composition and size, for all households in the FBS 2002 data file that satisfied the requirements for entitlement to the housing allowance. The computation of effectiveness under real (or lower) allowance take-up has not been possible as we could not simulate which households apply for an allowance and which ones do not. The effectiveness of housing allowance was thus evaluated not as a real effect but as the potential effectiveness if all eligible households were to apply for it. This distinguishes it from other evaluations but the measurement of subsidy effectiveness in this way may lead to its better understanding (especially when actual take-up is temporarily skewed). The

\footnotetext{
8 The taxpayers who submitted their personal tax declarations in 2002 were not, probably, typical taxpayers. The income tax declarations for the large share of the employees (who do not have any other income than the income from one employment contract) were submitted by their respective employers but these declarations were not electronically recorded or summarized. Own tax declarations thus represented the only available source of data and there was also no option to correct the sample selection bias. It can be assumed that people submitting their own tax declarations had a somewhat higher income and this limitation was stressed in the presentation of results.
} 
consequences of lower take-up for the evaluation of allowance effectiveness will be discussed below in the presentation of the results.

All the housing subsidies tested can be regarded as a certain form of housing consumption (income) redistribution. According to the principle of vertical effectiveness, redistribution should be directed from the rich to the poor in a manner that leads to a reduction in social inequality. According to the principle of horizontal effectiveness no needy (lower income) household should be excluded from eligibility for the subsidy. If the condition of vertical effectiveness is met, then the absolute amount of subsidy should be significantly higher in the group of lower-income households than in the group of higherincome households, i.e., it should contribute to reducing the level of income inequality. Given that the income of households with more members tends to be higher, attention was paid not only to the distribution of subsidies according to the net household income but especially according to the equivalent income, i.e., household income adjusted according to the OECD equivalence scale. ${ }^{9}$ We thus used following assumptions on vertical and horizontal effectiveness:

Main assumption 1 Effective subsidies assist lower-income (needy) households more than higher-income (less needy) households (vertical effectiveness).

Sub-assumption 1 The absolute amount of subsidy should be significantly higher in the group of lower-income (needy) households than in the group of higher-income households (less needy).

Sub-assumption 2 The subsidy should contribute to reducing the level of inequality in income distribution.

Main assumption 2 Effective subsidies are those whereby no lower-income (needy) household is excluded from eligibility for it (horizontal effectiveness).

For an evaluation according to sub-assumption 1 we applied standard statistical tests. No general rule can be found in the literature in this field about how to determine at what rate of redistribution a given instrument exhibits high effectiveness and at what rate of redistribution its effectiveness is poor. Setting such limits is always largely a normative decision. For the purpose of the following analyses it was additionally assumed that if $90 \%$ of the total sum of resources distributed by means of a given instrument went to $50 \%$ of the lowest-income households and at the same time $75 \%$ of the total sum of resources went to $30 \%$ of the lowest-income households, then the given instrument shows a relatively high degree of effectiveness.

For an evaluation according to sub-assumption 2 we used indicators of inequality as presented, for example, in Barr (1998, pp. 149-152). These indicators were used to compute income inequality without application of this particular subsidy and after its application; the difference shows whether the subsidy reduced income inequality or not. One of the simplest indicators of income inequality is the standard deviation computed as follows:

$$
V=\sqrt{\frac{1}{n} \sum_{i=1}^{n}\left(y_{i}-\mu\right)^{2}},
$$

where $y_{i}$ is income of household $i, \mu$ is average income $n$ is number of households.

\footnotetext{
${ }^{9}$ OECD equivalence scale is derived from the number and age of individual household members: for the household head the weight is equal to 1.0 , for children aged $0-13$ it is 0.5 , and for each additional household member it is 0.7 .
} 
The disadvantage of the use of the standard deviation is that it is sensitive to the absolute income level. This may be eliminated by the coefficient of variation, which standardizes the standard deviation in relation to mean income, as follows:

$$
C=\frac{\sqrt{V}}{\mu}
$$

The main disadvantage of the coefficient of variation is that it does not take into account the level at which income redistribution occurs. In other words, if CZK 1,000 is transferred from a household with an income of CZK 20,000 to a household with an income of CZK 6,000 , it expresses itself in the value of the coefficient of variation equally to what it would if CZK 1,000 were transferred from a household with an income of CZK 500,000 to a household with an income of CZK 400,000. The variance of the log-income makes it possible to take into account the greater weight of redistribution in favor of low-income groups, as follows:

$$
H=\frac{1}{n} \sum_{i=1}^{n}\left(\log y_{i}-\log \mu\right)^{2}=\frac{1}{n} \sum_{i=1}^{n} \log \left(\frac{y_{i}}{\mu}\right)^{2}
$$

Probably the most commonly used measure of income inequality is the Gini coefficient (represented by the Lorenz curve). Each point on the Lorenz curve denotes what portion of the total income is distributed among $x$ percent of the lowest-income population. The Gini coefficient is calculated as one-half of the arithmetic mean of the absolute value of the differences between all the pairs of incomes standardized in relation to the mean income $G=\frac{1}{2 n^{2} \mu} \sum_{i=1}^{n} \sum_{j=1}^{n}\left|y^{i}-y^{j}\right|$

Another recommended indicator of income inequality is the ratio between the mean income of $5 \%$ of the highest-income households and the mean income of $5 \%$ of the lowest-income households (hereafter this indicator will be referred to as $W$ ). All the aforementioned indicators, with the exception of the Gini coefficient (the Lorenz curve will only be used to illustrate the distribution of subsidy), will be used in the following analyses.

For an evaluation according to the main assumption 2 we studied thoroughly the conditions of housing subsidy allocation in the overall housing and social policy context. This helped us to estimate whether there could be a group of needy (low-income) households that is explicitly or factually excluded from eligibility for the housing subsidy.

\section{Effectiveness of selected housing subsidies in the Czech Republic}

\subsection{Rent regulation}

Just like other housing policy instruments, the existence of rent regulation could be justified by two concerns: inefficient functioning of a market and/or redistribution of means toward low-income households. There is no reason to implement such a form of state intervention for the purpose of increasing the efficiency of housing market functioning (when we compare the values of the usually used indicators of housing stock penetration, ${ }^{10}$

${ }^{10}$ Such as the number of flats per 1,000 inhabitants or per 100 households. 


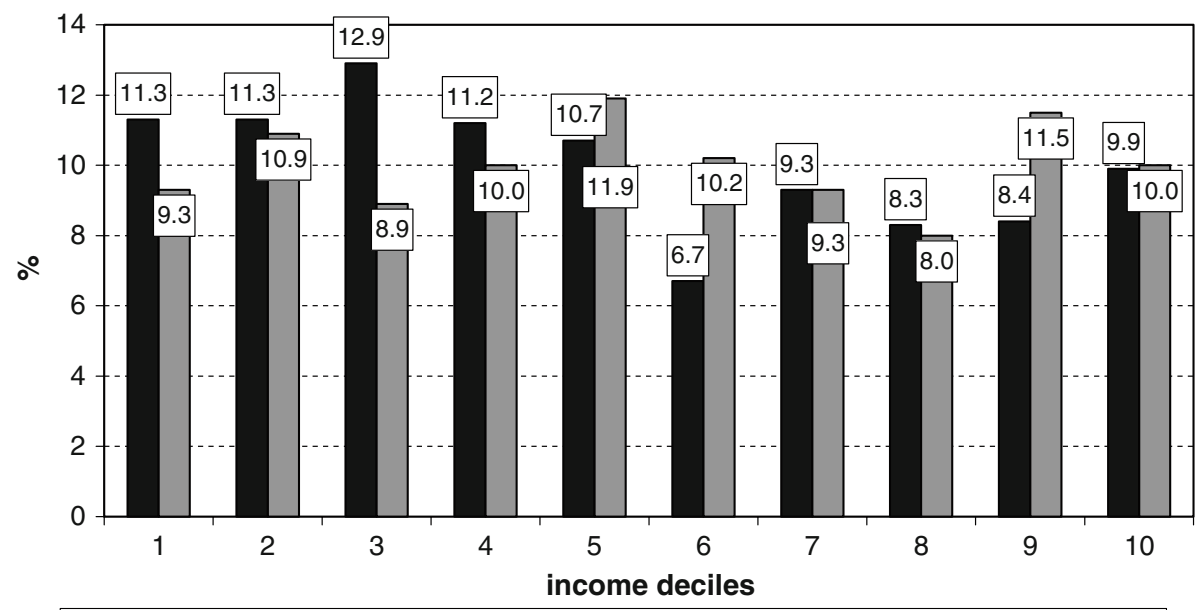

percentage of households living in flats with regulated rent by deciles of total net household income $\square$ percentage of households living in flats with regulated rent by deciles of total net equivalent income

Fig. 1 The percentage of households "profiting" from regulated rent, 2002. Source FBS 2002. $N=3,290$, $n=688$

the Czech Republic does not suffer from a housing shortage compared to the old EU countries; the suspicion of the existence of a monopoly in the area of private rental housing is also unjustified). Moreover, the effectiveness of rent regulation is also very poor. Figure 1 shows the percentage of households living in the regulated rent housing sector among the total number of households in individual categories according to the total household income or equivalent household income. As is clear, rent regulation was almost equally applied to "rich" and "poor" households. As many as $10 \%$ of the wealthiest Czech households (10th decile of the income distribution) lived in a flat with regulated rent and this percentage was not significantly lower than among the poorest households (1st decile of the income distribution-9.3\%). The hypothesis was tested as to whether households living in flats with regulated rent are roughly equally represented across individual income deciles. This hypothesis cannot be rejected as the results of the chi-square test indicate a 95\% level of significance.

Figure 2 shows how the total hidden economic subsidy following from rent regulation is distributed; the total hidden subsidy is defined as a difference between the estimated market equilibrium rent price and the current regulated rent price. The equilibrium market rents in 2002 were estimated in Lux and Sunega (2004) and adjusted in Lux et al. (2004). Actual "market" rents (allowed for new tenancies) could hardly be considered to be the equilibrium market rents as they were squeezed up due to the rent regulation for running tenancies. The equilibrium market rents were therefore computed in a relatively complex way. Using the Family Budget Survey statistics, we gradually increased the regulated rents for households living in rent-controlled housing and based on rational choice theory we simulated the outflow of households from rental to owner-occupied housing under new rental prices (tenure choice and user costs concepts were applied). The equilibrium market rents were equal to the increased regulated rents when the number of households leaving the sector of regulated housing evened out the number of households living in market rental housing in a particular country/region. If such equilibrium market rents were not 


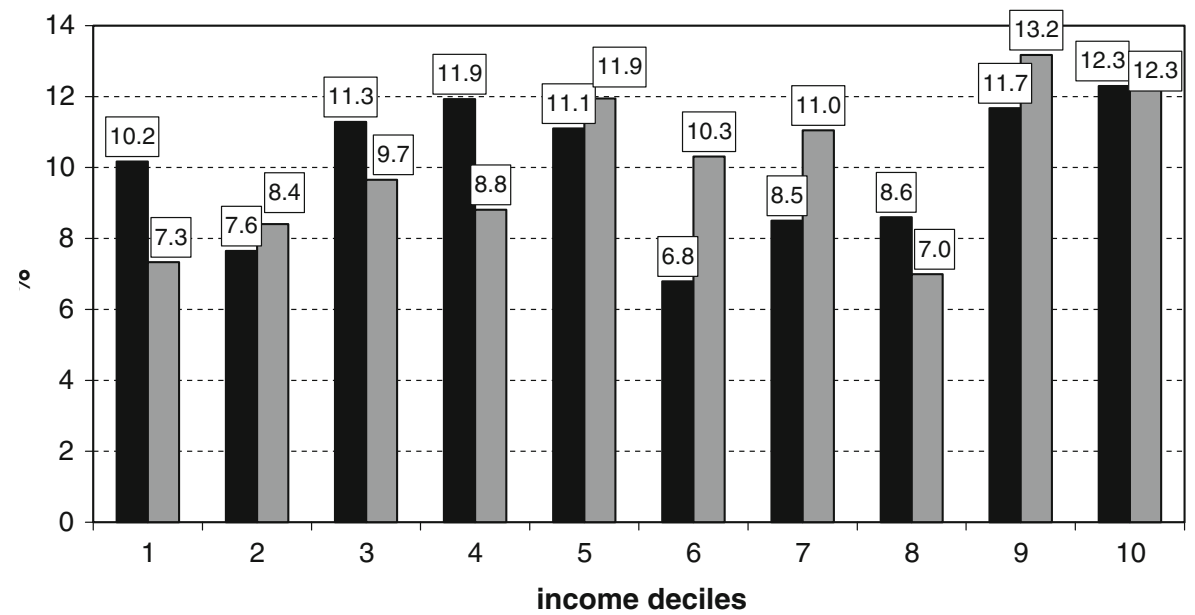

distribution of the sum of the hidden subsidy from rent regulation by deciles of total net household income (\%), distribution of the sum of the hidden subsidy from rent regulation by deciles of total net equivalent income (\%)

Fig. 2 Distribution of the hidden economic subsidy following from rent regulation according to household income (ten household income deciles), 2002. Source FBS 2002; Author's calculations. $N=3,290$

giving appropriate yield to private landlords, we assumed the additional sale of dwellings and simulated the house price decrease-equilibrium market rents were then adjusted to this price change. It is clear from Fig. 2 that it was especially the wealthiest and the medium-income households that "profited" from economic subsidy following from the rent regulation in 2002 .

It was also tested whether the average level of the economic subsidy differs between income deciles. The LSD test shows that the average level of subsidy for households in the last two equivalent income deciles was statistically significantly higher than the average level of subsidy to the lowest-income households in the first two equivalent income deciles. The criterion selected to indicate an instrument's high effectiveness was the kind of redistribution where $90 \%$ of the total sum of the subsidy goes to $50 \%$ of the households with the lowest incomes and at the same time $75 \%$ of the total sum of the subsidy goes to $30 \%$ of the households with the lowest incomes. The economic subsidy following from rent regulation failed to satisfy this criterion. Only around $46 \%$ of the total amount of the subsidy was received by $50 \%$ of the households with the lowest equivalent incomes, and $30 \%$ of the households with the lowest equivalent incomes received only $25 \%$ of the economic subsidy.

In Table 2 the values of different indicators of income inequality are summarized; they were calculated using equivalent income, first without the subsidy and then with the economic subsidy (i.e., the household income was increased by the amount of the subsidy). The figures clearly show that while the standard deviation, variance of the log-income and mean income ratio of $5 \%$ of the highest-income and 5\% of the lowest-income households indicate that income inequality increased in society after the allocation of the economic subsidy, only the variation coefficient indicates the opposite trend. The reason why the variation coefficient shows the opposite trend is probably the fact that to a large extent middle-income (and highest-income) households profit from the subsidy. As the variation coefficient is not sensitive to the level at which redistribution takes place, the value of the 
Table 2 Indicators of the level of inequality of income distribution before and after the hidden economic subsidy from rent regulation

\begin{tabular}{lll}
\hline Indicator & Without the subsidy & With the subsidy \\
\hline Standard deviation (V) & 4786.4 & 5102.5 \\
Variation coefficient (C) & 0.482 & 0.456 \\
Variance of log-income (H) & -0.054 & -0.055 \\
Mean income ratio (W) & 4.18 & 4.19 \\
\hline
\end{tabular}

Source: FBS 2002; Author's calculations

coefficient indicates lower inequality in income distribution after the subsidy. However, the most informative is probably the variance of the log-income, which gives greater weight to lower-income groups.

In all systems of rent regulation (social housing) some low-income households may be factually excluded from the right to get rent-regulated housing (immigrants, non-residents etc.). However, the system applied in the Czech Republic was, from the point of view of horizontal effectiveness, even more discriminating. The rent regulation and strong tenant protection had the character of a safety net for existing tenants while new households had, due to the low tenant turnover and the end of mass state rental housing construction, few chances to get involved (Lux 2004). Though it is hardly explicitly measurable, the substantial part of needy new households (young couples and families, singles after divorce) were, in fact, completely excluded from eligibility for this type of subsidy.

\subsection{Housing allowance}

The housing allowance is an income-tested state subsidy, and therefore it is possible to assume that in comparison with the other instruments it will be a relatively effective one. Based on simulations using the FBS 2002 data, Fig. 3 shows the distribution of the sum of the housing allowances among households according to the total net household income and household equivalent income under the assumption of $100 \%$ allowance take-up. Table 3 presents the values of the indicators of equivalent income inequality before and after the housing allowance. The housing allowance satisfied the normative criterion of effectiveness: $50 \%$ of the lowest-income households would be the recipients of $99 \%$ of the total sum that would be paid in housing allowances, and $30 \%$ of the lowest-income households would receive approximately $97 \%$ of this total amount. As is clear from Table 3, this form of the housing allowance contributed unequivocally to reducing income inequality in society, and from this perspective it can be regarded as effective.

However, the failure of the Czech housing allowance was the fact that real housing expenditures did not enter the equation but instead only the flat-rate component of the subsistence minimum was used (tariff housing costs). In consequence, it breached the assumption of horizontal effectiveness. This failure is a very serious one, and it is probably one of the reasons why a large portion of eligible households did not apply for this social benefit. The housing allowance was provided to homeowners who usually spent a relatively small portion of their income on housing, as well as tenants whose family budgets were far more burdened with housing costs. The distribution of the sum of potentially paid housing allowances among households with varying levels of housing expenditure-toincome ratio (the 1 st decile corresponds to the lowest level of housing expenditure-toincome ratio) under the situation of $100 \%$ take-up is presented in Fig. 4. It appears that the 


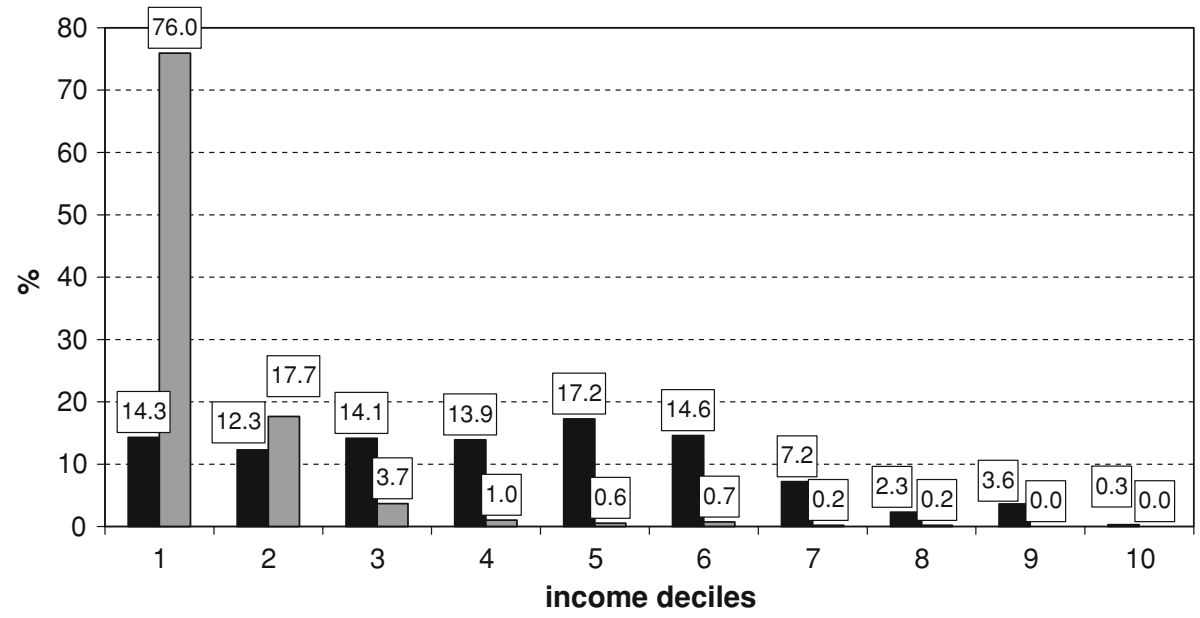

distribution of the sum of the housing allowance by deciles of total net household income (\%) $\square$ distribution of the sum of the housing allowance by deciles of total net equivalent income (\%)

Fig. 3 Distribution of the housing allowance (assumed 100\% take-up) according to household income (ten household income deciles), 2002. Source FBS 2002. $N=3,292$

Table 3 Indicators of the level of inequality of income distribution after the housing allowance is taken into account

\begin{tabular}{lll}
\hline Indicator & Without the housing allowance & With the housing allowance \\
\hline Standard deviation (V) & 4465.5 & 4439.9 \\
Variation coefficient (C) & 0.448 & 0.445 \\
Variance of log-income (H) & -0.054 & -0.052 \\
Mean income ratio (W) & 4.02 & 3.82
\end{tabular}

Source: FBS 2002; Author's calculations

allowance did not adequately target households with higher expenditure-to-income ratio, as, for example, $5 \%$ of the sum of potentially paid allowances would be distributed among households with the lowest level of this ratio. Another serious consequence of income ceiling and low cost tariffs applied in the allowance formula is that they completely excluded all households paying market rents, i.e., households paying rents several times higher than the regulated rents and tariffs. The income of those households often exceeded the ceiling though their effort ratio might be very high. The potential housing allowance computed from tariffs would be, even in the case of low income, insignificant and would not allow them to stay in the flat.

\subsection{Tax relief}

The distribution of tax relief is clearly diverted to the benefit of the highest income taxpayers (Fig. 5). The Figure captures the distribution of the subsidy among those taxpayers who submitted their own income tax declarations in 2002; an estimate for all taxpayers is impossible due to the unavailability of data. As these are not typical taxpayers 


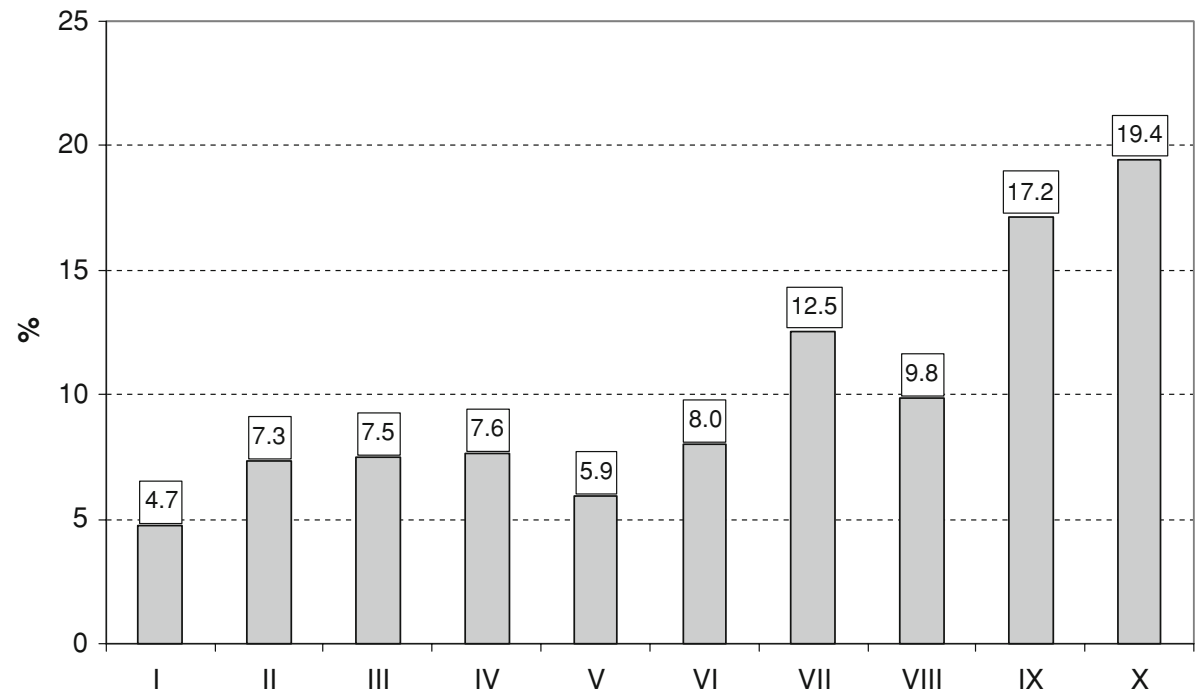

Fig. 4 Distribution of the housing allowance (assumed 100\% take-up) according to the housing expenditures-to-income ratio (ten ratio deciles), 2002. Source FBS 2002. $N=3,292$

and they are probably of higher income the real subsidy distribution may be more equalized. Fig. 5 shows that taxpayers with the highest gross income (the 10th income decile) benefited most from the tax relief. This is not really a surprising finding in view of the fact that often only these people met the solvency criteria of the banks in 2002. The tax relief is again an instrument that does not fulfill the selected criterion of effectiveness: $50 \%$ of the low-income taxpayers used only $1.3 \%$ of the total paid subsidy, and $30 \%$ of the lowest-income taxpayers benefited from only $0.43 \%$ of the total subsidy (with caution due to the data limitations). We could not compute the values of income inequality indicators because only the cumulative percentage distribution of the subsidy among specific income groups (deciles) was provided by the Ministry of Finance. The individual data necessary to calculate the values of other indicators were not available. From the perspective of horizontal effectiveness, factually all lower-income taxpayers were excluded from this subsidy as they would not meet the solvency criteria of the banks in 2002.

\subsection{Supply side subsidies}

Social rented housing has not been defined in the Czech Republic on the central level and was only occasionally defined on the local level (municipalities). Altogether, taking a very broad definition of social housing as administratively allocated public housing with lower than market rents, then we would count all existing rent-regulated municipal housing (constructed before 1989), all new municipal housing with cost rent constructed during the transition (even some "quasi-rental" municipal flats) and all supported municipal housing (for example housing with social care) constructed during the transition. The total would reach 610,000 municipal dwellings in 2001 (17\% of the housing stock). However, taking a more serious definition of social housing as rental housing with rents below market rates and allocated administratively according to income and social situation of the applicant, then we would count only that existing municipal housing that was vacated and rented out 


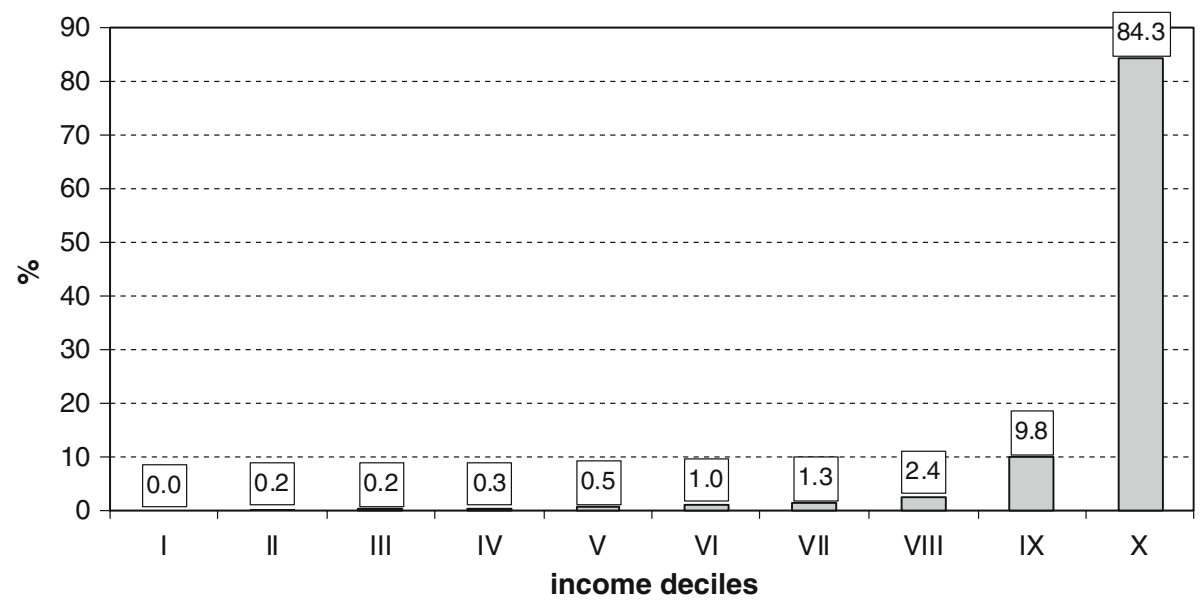

Fig. 5 Distribution of the fiscal loss following from the tax relief, according to the personal income from economic activity (taxpayers submitting own tax declarations, ten personal income deciles), 2002. Source Ministry of Finance

again during the transition at regulated rents to those in need (by very rough estimate about 6,000 flats), only that new municipal housing that was constructed since 2003 when subsidies on municipal housing construction stopped to be abused (about 7,000 flats), new supported housing (2,568 flats) and new housing with social care (7,500 flats) - in this case the total would be only about 23,100 dwellings in 2006 , that is about $0.6 \%$ of the housing stock. The gap between both figures $(17 \%$ versus $0.6 \%)$ intuitively shows how ineffective the housing policy in the field of supply-side subsidies was at targeting those in need.

\subsection{State premium for the housing savings scheme}

Though constituting the highest direct state housing expenditure (more than half of the state housing policy spending), we know nothing about the recipients of state premiums to housing saving schemes. We cannot measure the effectiveness of this subsidy because there are almost no data (housing savings banks are not obliged to provide anything like that). The only proof is drawn from sociological surveys (on a national sample of population) asking people whether and how they use the housing savings scheme.

One such survey, Housing Attitudes in the Czech Republic conducted by the Institute of Sociology on a national sample of 3,357 respondents in 2001, proved that $48 \%$ of those who rank their household as low-income do not have and do not intend to have a housing savings account while the same applies to only $26 \%$ of those who rank their household as middle-income and $21 \%$ of those who rank their household as high-income (altogether $7 \%$ of respondents perceive their household as being high-income, $45 \%$ as being middleincome, and $48 \%$ as being low-income). As indicated by adjusted residuals, those who rank their household in the middle-income group use or intend to use the scheme significantly more for general savings (i.e., it will not be used for housing purposes) and those who rank their household in the high-income group significantly more use or intend to use the scheme (both savings and loans) for housing purposes. The differences in housing savings state premium take-up among respondents according to the perceived income situation of their households are statistically highly significant (Pearson chi-square had a value of 223 
with 8 degrees of freedom) with a significantly higher take-up among middle- and highincome households than among low-income households. This shows that the effectiveness of state premiums for housing savings is, very probably, also low.

\section{Conclusions}

In this paper we tried to apply the theory and methodological device of welfare economics to evaluate selected housing subsidies in the Czech Republic. We especially paid attention to the subsidies' effectiveness, which relates to the wealth redistribution directed by the state. In other words, we tested whether state housing subsidies are allocated especially among those in need and whether they contribute to decreasing income inequality in Czech society.

The presented social justice theories explained why it is in the rational interest of the state to conduct at least residual wealth redistribution, including the use of subsidies to stimulate housing consumption. According to the common "rational imperative" of redistribution present in the selected theories the subsidies should especially target the "worse-off" and thus lower the level of wealth (housing consumption) inequality. The concept of vertical and horizontal effectiveness of subsidies was applied to determine the set of main assumptions reflecting this imperative and the assumptions were then tested in the subsequent empirical analysis. For measurement of vertical effectiveness several statistical and inequality indicators were used.

Figure 6 depicts an attempt to capture the distribution of selected Czech housing subsidies in a Lorenz curve. In view of the fact that many subsidies are not income-tested and thus the income of applicants cannot be ascertained even from other alternative sources (as is the case, for example, with the state premium for the housing savings scheme), we could only present the distribution of the housing allowance (according to the equivalent

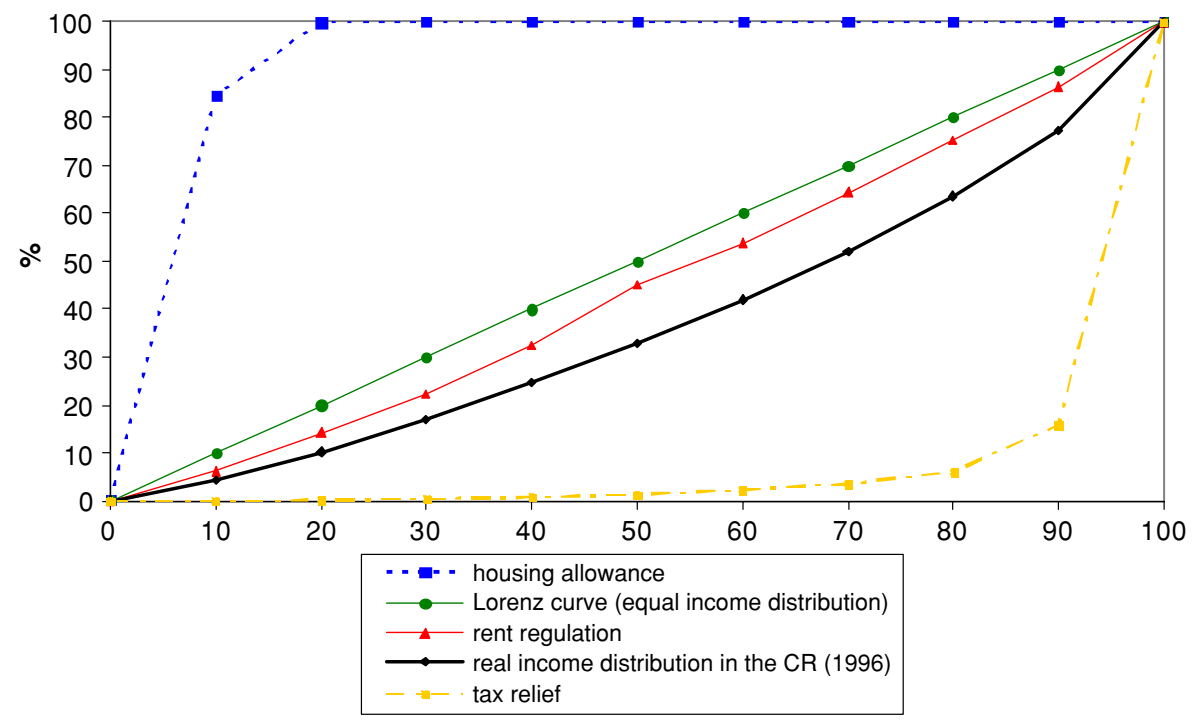

Fig. 6 Distribution of incomes and selected housing subsidies in Lorenz curve. Source FBS 2002, Mikrocensus 1996, Ministry of Finance, own calculations 
household income and FBS 2002 simulations), the distribution of an indirect fiscal subsidy following from the tax relief (according to the total gross income of a taxpayer, applicable only to people submitting their own tax declaration and according to the Ministry of the Finance) and a distribution of the hidden economic subsidy following from rent regulation (according to equivalent household income and FBS 2002 simulation).

Among the selected housing policy instruments, the housing allowance was most targeted at the households with the lowest income; practically the entire volume of state funds paid out in the form of the housing allowance were divided among the $20 \%$ of households with the lowest income. The curve capturing the distribution of the economic subsidy following from rent regulation most approximates the curve of equal income distribution. On the contrary, from the tax relief benefits in particular people with the highest income; $90 \%$ of the taxpayers divided among themselves less than $20 \%$ of the total volume of this subsidy, while the remaining $80 \%$ went to the $10 \%$ of the taxpayers with the highest incomes. Other housing policy tools, such as supply side subsidies and state premiums for housing savings, could not be measured in the same way. However, we provided at least partial proof that the effectiveness of both tools was probably also low. Moreover, though housing allowance was targeted to households with a low income, it failed to better target households with a high housing expenditure-to-income ratio. The tariff costs incorporated in the allowance formula ignored the existence of market rental housing with substantially higher rents. These were serious drawbacks from the point of view of horizontal effectiveness.

To wrap up the conclusions, we present some possible explanations for the low level of effectiveness of housing subsidies in the Czech Republic. It could be argued that the Czech government was reluctant to surrender control over the main levers that decisively influence the form of the housing system during the transition to a market economy. In this way it preserved the housing privileges for existing occupants of rental housing by granting them low rents and a generous tenant protection. Relatively low effectiveness of economic subsidies stemming from rent controls is an outcome of this process. The continued government attention to extensive housing policy outcomes (like the scale of housing construction) and inequalities in housing allocation that had survived from the previous regime could also explain why even new housing policy measures were badly targeted to those in need. Though we know little about the real causes, this fact does not alter the imperative that remains before the Czech government-to improve the effectiveness of housing subsidies before the negative consequences of the current settings increase inequalities to too high levels.

Acknowledgments The work on this article was supported by the Grant Agency of the Czech Republic, grant No. 403/09/1915.

\section{References}

Abraham, J. M., \& Hendershott, P. H. (1996). Bubbles in metropolitan housing markets. Journal of Housing Research, 7, 191-207.

Barker, K. (2003). Review of Housing Supply. Securing our Future Housing Needs. Available on-line on http://www.hm-treasury.gov.uk.

Barr, N. (1993, 1998). The economics of the welfare state. London: Weidenfeld and Nicolson.

Boddy, M. (1989). Financial deregulation and UK housing finance: Government-building society relations and the Building Society Act. Housing Studies, 4, 92-104. 
Boelhouwer, P. J., \& van der Heijden, H. M. H. (1992). Housing systems in Europe. Delft: Delft University Press.

Bull, G. (1998). The Economics of Housing. In P. Balchin \& M. Rhoden (Eds.), Housing, essential foundations. London, NY: Routledge.

Clapham, D., Hegedüs, J., Kintrea, K., \& Tosics, I. (1996). Housing privatisation in Eastern Europe. Westport: Greenwood Press.

Clapham, D., Kemp, P., \& Smith, S. (1990). Housing and social policy. Basingstoke: Macmillan.

Diamond, D. B. (2005). Thinking about subsidies to housing finance. In J. Hegedüs, R. J. Struyk, \& Housing Finance (Eds.), New and old models in central Europe, Russia, and Kazakhstan (pp. 79-98). Budapest: Open Society Institute (LGI).

Donner, Ch. (2006). Housing policies in central Eastern Europe. Vienna: Donner.

Dübel, A. (2000). Housing subsidy expenditures in the Czech Republic public expenditure review for the Czech Republic. Washington, DC: World Bank.

Fallis, G. (1985). Housing economics. Toronto: Butterworths.

Just, R., et al. (2004). The welfare economics of public policy. Cheltenham and Northampton: Edward Elgar.

Kemeny, J. (1992). Housing and social theory. London, NY: Routledge.

Kemeny, J. (1995). From public housing to the social market. London: Routledge.

Kleinman, M. (1996). Housing welfare and the state in Europe. Cheltenham: Edward Elgar.

Lérová, I. (1983). Úloha bydlení vsociálně ekonomickém rozvoji (The role of housing in socio-economic development). Prague: SNTL.

Lowe, S., \& Tsenkova, S. (Eds.). (2003). Housing change in east and central Europe. Integration or fragmentation? London. New York: Ashgate.

Lundqvist, L. (1988). Corporate implementation and legitimacy. Housing Studies, 3, 172-182.

Lundqvist, L. (1992). Dislodging the welfare state? Housing and privatization in four European countries. Delft: Delft University Press.

Lux, M. (2001). Social housing in the Czech Republic, Poland and Slovakia. European Journal of Housing Policy, 1(2), 189-209.

Lux, M. (2003a). Efficiency and effectiveness of housing policies in the central and eastern Europe countries. European Journal of Housing Policy, 3(3), 243-265.

Lux, M. (Ed.). (2003b). Housing policy: An end or a new beginning. Budapest: LGI.

Lux, M. (2004). Housing the poor in the Czech Republic: Prague, Brno and Ostrava. In J. Fearn (Ed.), Too poor to move, too poor to stay (pp. 23-66). Budapest: LGI.

Lux, M. (2006). Housing systems' change on the Way to EU-similarities and differences, integration or convergence paper. Ljubljana: ENHR conference. July 2006.

Lux, M., \& Sunega, P. (2004). Modelování rovnovážné úrovně nájemného a důsledků aplikace vybraných nástrojů bytové politiky [Modelling of market rent equilibrium and consequences of housing policy tools' application]. Finance a úvěr [Czech Journal of Economics and Finace], 53, 31-59.

Lux, M., Sunega, P., Kostelecký, T., \& Čermák, D. (2003). Standardy bydlení2002/03: Finančnídostupnost a postoje občanuं (2002/03 Housing standards: Financial affordability and attitudes towards housing). Prague: Institute of Sociology.

Lux, M., Sunega, P., Kostelecký, T., Čermák, D., \& Košinár, P. (2004). Standardy bydlení2003/04: Bytová politika: efektivněji a clleněji (2003/04 Housing standards: Housing policy: Efficiency and effectiveness). Prague: Institute of Sociology.

Lux, M., Sunega, P., Kostelecký, T., Cermák, D., \& Montag, J. (2005). Standardy bydlení 2004/2005: Financování bydlení a regenerace sídliš̃. (2004/2005 Housing standards: Housing finance and regeneration of high-rise housing). Prague: Institute of Sociology.

Lux, M., Sunega, P., Obadalová, M., Vajdová, Z., \& Čermák, D. (2002). Bydlenı́-věc veřejná (HousingRes Publica). Prague: SLON.

Maclennan, D. (1982). Housing economics. London, NY: Longman.

Malpezzi, S., \& Green, R. K. (2003). A primer on US housing markets and policy. Washington, D.C: The Urban Institute Press, for the American Real Estate and Urban Economics Association. Monograph Series, No. 3, 2003.

Mandic, S. (2000). Trends in central east European rented sectors. Journal of Housing and the Built Environment, 15(3), 217-231.

Mareš, P. (2001). Problém nečerpánísocialnich dávek (The problem of low take-up of social benefits). Brno: VÚPSV.

Mildschuh, V., Dušek, R., \& Herman, K. (1931). Knaší otázce bytové (On housing question). Prague: Prometheus.

Muellbauer, J., \& Murphy, A. (1997). Booms and busts in the UK housing market. The Economic Journal, 107(445), 1701-1727. 
Muth, R. F., \& Goodman, A. C. (1989). The economics of housing markets. London: Harwood Academic Publishers.

National Control Office. (2006). Hospodařenís finančními prostředky státnıho rozpočtu určenými na programy bytové vystavby a bydleni. (The use of financial sources of the state budget assigned on programs of housing construction and housing). Bulletin of the National Control Office No. 2 (pp. 169177). Prague: NKU.

Ng, Y.-K. (1983). Welfare economics. London: Macmillan.

Office, National. Control. (2004). Prostředky Státniho fondu rozvoje bydleni. (The means of the State Fund for Housing Development). Bulletin of the National Control Office No. 2 (pp. 149-159). Prague: NKU.

Pichler-Milanovich, N. (2001). Urban housing markets in central and eastern europe. Convergence, divergence or "policy collapse". European Journal for Housing Policy, 1(2), 145-187.

Poláková, O., et al. (2006). Bydlenía bytová politika (Housing and Housing policy). Prague: Ekopress.

Quigley, J. M. (1997). The economics of housing (Vol. I\&II). Cheltenham: Edward Elgar.

Rawls, J. (1971). A theory of justice. Harvard: The Belknap Press of Harvard University Press.

Schmidt, S. (1989). Covergence theory, labour movements and corporatism: The case of housing. Scandinavian Housing and Planning Research, 6, 83-101.

Struyk, R. (Ed.). (1996). Economic restructuring of the former Soviet Bloc. The Case of Housing. Washington, DC: The Urban Institute.

STÚ-E. (2007). Analyźa vývoje porizovacích a udržovacích cen bytových domu (Analysis of building and maintenance costs of multidwelling residential houses). Prague: Ministry for Regional Development.

Sýkora, L. (2003). Between the state and the market: Local government and housing. In M. Lux (Ed.), Housing policy: An end or a new beginning (pp. 48-116). Budapest: LGI-OSI.

Sýkora, L., \& Šimoníčková, I. (1994). From totalitarian urban managerialism to a liberalized real estate market. In M. Barlow, P. Dostál, \& M. Hampl (Eds.), Development and administration of Prague (pp. 47-72). Amsterdam: University of Amsterdam.

Tosics, I., \& Hegedüs, J. (1998). Rent reform-issues for the countries of eastern Europe and the newly independent states. Housing Studies, 13, 657-678.

ÚRS. (2005). Rozvoj sídliš̌ a rekonstrukce bytového fondu v ČR (High-rise housing development and refurbishment of the housing stock in the Czech Republic). Prague: ÚRS. 